\title{
THE REALIZATION OF SPEECH FUNCTION IN ENGLISH CLASSROOM INTERACTION BASED ON SYSTEMIC FUNCTIONAL LINGUISTICS THEORY
}

\author{
AN ARTICLE \\ Submitted in Partial Fulfillment of the Requirements \\ for the Degree of Sarjana Pendidikan
}

By

ARINI SUPIKA

Registration Number: 2133121009

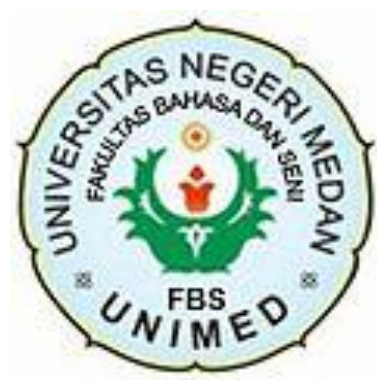

ENGLISH AND LITERATURE DEPARTMENT

FACULTY OF LANGUAGES AND ARTS

MEDAN STATE UNIVERSITY

2017 
ARTIKEL

THE REALIZATION OF SPEECH FUNCTION IN ENGLISH CLASSROOM INTERACTION BASED ON SYSTEMIC FUNCTIONAL LINGUISTICS THEORY

Disusun dan Diajukan oleh:

Arini Supika

Registration Number: 2133121009

Telah diverifikasi dan dinyatakan memenuhi syarat untuk diunggah pada jurnal online

Medan, November 2017

Menyetujui

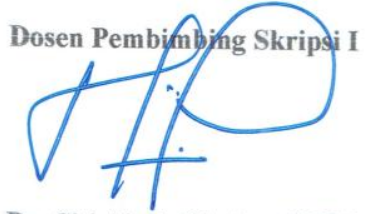

Dr. Siti Aisah Ginting, M.Pd. NIP. 195705211984032002

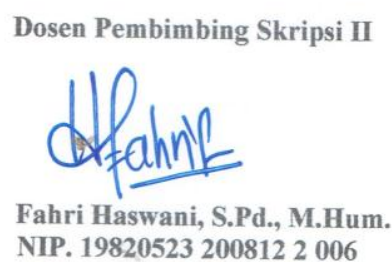

Ka. Program Studi Pendidikan Bahasa Inggris

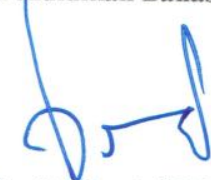

Nora Ronita Dewi, S.Pd., S.S., M.Hum.

NIP. 198005222008122003 


\title{
THE REALIZATION OF SPEECH FUNCTION IN ENGLISH CLASSROOM INTERACTION BASED ON SYSTEMIC FUNCTIONAL LINGUISTICS THEORY
}

\author{
*Arini Supika \\ **Siti Aisah Ginting \\ **Fahri Haswani
}

\begin{abstract}
This study deals with speech functions used by teacher and students during reading comprehension session in English vocational classroom interaction. The objectives of this study were to find out the types of speech function which were dominantly used by teacher and students and the reasons for the existences of that dominant one. A descriptive qualitative design was used in this study. The data were collected by observing, recording the utterances of teacher and the tenth grade students at SMK Jambi Medan, and by interviewing the subjects. The data were analyzed based on Systemic Functional Linguistics theory. There were 552 clauses produced as the total number where teacher produced 411 clauses and students produced 141 clauses. The results showed that question was the dominant type of speech function used by teacher followed by statement, acknowledgement, command, contradiction and offer. Meanwhile, the dominant type of speech function used by students was answer, followed by compliance, statement, acknowledgement, and disclaimer. The existences of initiating question on the teacher's performance were affected by the presage category (teacher's belief) and context category (the class in which the teaching process takes place), while, the existences of answer on the students' performance were affected by the students' thought processes category (students' perception and understanding) and the context category. In conclusion, the teacher used the speech function which focused on using initiation of question, while students dominantly used answer speech function in English classroom interaction.
\end{abstract}

Keywords: Speech Function, Classroom Interaction, Systemic Functional Linguistics. Descriptive-Qualitative.

*Graduate

** Lecturer 


\section{INTRODUCTION}

\section{Background of the Study}

Language plays an important role in undergoing human's daily routine activities. As a member of the society, people adopt one of the metafunction of language that is interpersonal function. It is the use of language to exchange experience which means that language is organized as an interactive event involving speaker or writer, and audience. When they are communicating each other, they obviously produce sentences that consist of its meaning and structures. Here, the semantic aspect (meaning) of sentence is termed as speech functions and at the level of lexicogrammar (structural form), an aspect of interpersonal function is termed as mood (Saragih, 2014:40).

Basically, Saragih (2014:37) states that speech function refers to a function performed by a speaker in a verbal interaction or conversation which specifies his or her role (asking and demanding) and the content or commodity transacted (information and goods \& services). It is used as the medium to exchange experiences among speaker and listener in order to fulfill their needs.

Furthermore, knowing the fact that the use of speech function is important in human's daily life, teaching and learning process in English vocational classroom interaction is also cannot be separated from the existences of speech function. Thereby, it is crucial to know how the information is presented by teacher and students in the classroom. It can be used to identify meaning and analyze the grammatical features of information being transferred, so that students can obtain a better understanding of what the classroom activities designed by the 
teacher in form of verbal classroom interaction by considering the use of speech functions (Saragih, 2014:47).

In English vocational classroom, the use of English by students as the target language is really crucial to be improved because they must be able to communicate orally and in writing accurately to support their compentences for their future career. However, there are still incompatibilities in the practice of teaching and learning process to respond what it is expected from the theory of the English language teaching which focussing on the students-centered.

Based on the researcher's observation in SMK Jambi Medan during the teaching and learning process of English which can be seen in appendix A, the researcher noticed that several students did not show their active participation in responding the teacher, only some students. They could not express their ideas or opinion related to the material discussion. So that, in answering the teacher's questions, they used Indonesian language. It was difficult for them to respond the teacher using English and even they tried to give the answer in English, they needed longer time then expressed it intermittently. Students only gave short answer when they were asked to answer the teacher's questions. Finally, the classroom interaction became monotonous and it was dominated by the teacher.

Therefore, this study was intended to analyze the classroom interaction focussing on the analysis of speech functions based on Systemic Functional Linguistics theory and to find out the reason for the existences of the dominant speech function which was performed by teacher and students based on the 
variables which might affected to each other in the teaching process in the English vocational classroom (Gage, 2009:47).

\section{REVIEW OF LITERATURE}

\section{Classroom Interaction}

According to Brown (2001:165), classroom interaction is the collaborative exchange of thoughts, feelings, or ideas between two or more people, resulting in a reciprocal effect on each other which takes place in the classroom. Thus, classroom interaction concerns with the existence of communicative interaction raised by both the teacher and students, and among all students in the classroom.

\section{Systemic Functional Linguistics}

Halliday (1994) has developed an approach to linguistics which performs language as a basic of constructing human being's experiences called as Systemic Functional Linguistics. According to Liu (2014:1238), Systemic Functional Linguistics (SFL) provides a social perspective to language study and regards language as a social semiotic resource. It describes how the language is used by people in accomplishing human's daily social life. Based on the SFL perspective, language has three main metafunctions which will be described as follows:

\section{a. The Ideational Function}

This function views language in order to organize the speaker's or writer's experience of the real and imaginary world that is, language refers to real or imagined person. In other words, this function is used by people in understanding, organizing, and expressing the concepts or perceptions of the world. 


\section{b. The Interpersonal Function}

Language is used not only to construe the speaker's experience. It is also used to indicate, establish, or maintain the social relationship between people. This function enables people to participate in building a communicative interaction among others. It includes forms of address, speech function and mood.

\section{c. The Textual Function}

Language is used to create written and spoken texts which is cohesive within themselves and which fit to the particular situation in which they are used. Textual function enables people to connect and give the relation for what is being spoken or written to the real world or to the real context of situation.

\section{Speech Function}

Speech function refers to a function performed by a speaker in a verbal interaction or conversation which specifies his or her role, the orientation taken by the interculators, and the content or commodity transacted (Saragih, 2014:37). In simply, when someone communicates or interacts with others, there will be the three elements which are involved, they are: (a) the orientation taken by the speaker can be either that of initiating or responding; (b) the role played which are giving and demanding; and (c) the commodity transacted which are information and goods and services. The involvement of roles and commodities appeared in conversations or interactions will be intersected, and the four speech functions are derived as described in the Table 2.1 below (Halliday, 1994:69): 
Table 2.1 Speech Functions

\begin{tabular}{|c|c|c|}
\hline \multirow{2}{*}{ Role in Exchange } & \multicolumn{2}{|c|}{ Commodity Exchanged } \\
\cline { 2 - 3 } & (a) Goods \& Services & (b) Information \\
\hline \multirow{2}{*}{ (1) Giving } & $\begin{array}{c}\text { "Offer" } \\
\text { Would you like a cup of } \\
\text { coffee? }\end{array}$ & $\begin{array}{c}\text { He is giving him } \\
\text { coffee }\end{array}$ \\
\hline (2) Demanding & $\begin{array}{c}\text { "Command" } \\
\text { Give me a cup of coffee! }\end{array}$ & $\begin{array}{c}\text { "Question" } \\
\text { What is he give to me? }\end{array}$ \\
\hline
\end{tabular}

Source: Halliday (1994:69)

These basic types of speech role related to the nature of commodity being exchanged creates the four primary types of speech function, they are statement, offer, question, and command as what stated by Halliday (1994:69).

\section{The Realization of Speech Function in Mood}

The four primary types of speech function (offer, command, statement, and question) find their realizations in mood types or the mood structures which is an aspect of interpersonal meaning at the level of lexicogrammar (Saragih, 2014:40). Thus, in their unmarked or congruent representations, the four primary speech functions are realized or expressed by declarative, interrogative and imperative. The mood structures in English is described as in the Figure 2.1 below:

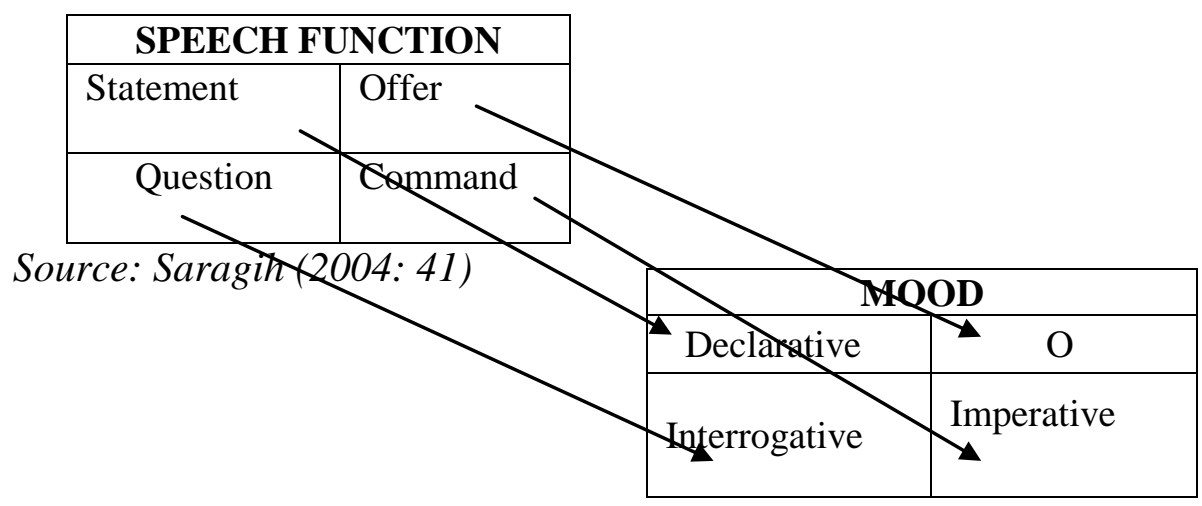

Figure 2.1 The Realizations of Speech Function in Moods 


\section{The Structure of Mood}

Eggins and Slade (1997:74-75) states that mood refers to the patterns of the clause type. The grammar of the clause realized in mood types is that the clause consists of two functional constituents of the clauses, a MOOD element (which describes the overall structure of the clause) and a RESIDUE element (part of the clause which is somehow less essential to the arguability of the clause than is the MOOD component). In the MOOD constituent, there are two essential component of the clause, Subject and Finite. Meanwhile, in the RESIDUE, it can contain a number of functional elements, nmely a Predicator,one or more Complements, and any number of different types of Adjuncts.

\section{Conception of Teaching}

According to the conception of teaching proposed by Gage (2004), there are variables which might affect to each other on the teacher's and students' performance. They are: (a) presage category: teacher's years of experience, characteristics, age, and the teacher's belief of the subject knowledge she is teaching; (b) context category: the characteristics of the nation, region, community, school, and class in which teaching takes place; (c) process category: which can also be broken down into three categories, namely, teacher thought process in planning, and deciding; teacher thought process and the content of teaching; and teacher thought process and students' thought process; and (d) product: represents the goal of all the foregoing categories. It includes achievement of cognitive objectives and can also refer to achievement of social emotional objectives. 


\section{RESEARCH METHODOLOGY}

This study deals with the use of speech function in the English vocational classroom. A descriptive-qualitative design was used in this study. Bogdan \& Biklen (1982) state that qualitative means to find out how a theory works in different phenomena whose data collected are in form of words rather than

numbers. In addition, descriptive qualitative design wass chosen in order to explore and understand the social phenomenon (Creswell, 2009:32). The data of this study were clauses used by teacher and students during the teaching and learning process. The subjects of this study were an English teacher and the tenth grade students of SMK Jambi Medan. In analyzing the data, it was analyzed by using the data analysis from (Saragih, 2014), these are the steps :

1. Transcribing the audio and video recording into the written transcript.

2. Segmenting the transcript that has several sentences into clauses.

3. Analyzing the clauses based on the types of speech function and moods.

4. Counting the realization of speech function and mood types

5. Conducting the interview section to the English teacher and the students

6. Giving the reasons for the existences of the dominant speech function

7. Drawing the conclusion. 


\section{DATA ANALYSIS AND RESEARCH FINDINGS}

\section{Data Analysis}

The analysis of speech function used in this study based on the three elements: (a) the orientation taken by the speaker: initiating or responding; (b) the role played: giving and demanding; and (c) the commodity transacted: information and goods and services (Halliday, $1994 \&$ Saragih, 2014). While, the reasons for the existences of the dominant speech functions uttered by the teacher and the students was categorized based on the variables that affect in English classroom interaction (Gage, 2004).

\section{The Findings}

Having analyzed the data, the findings can be seen as follows:

Table 4.1

Total Number and Percentages of Speech Functions (Initiating and Responding) of Teacher and Students in English Vocational Classroom Interaction

\begin{tabular}{|c|c|c|c|c|c|c|c|}
\hline \multirow[b]{2}{*}{ NO. } & \multirow{2}{*}{$\begin{array}{l}\text { Initiation of Speech } \\
\text { Function }\end{array}$} & \multicolumn{3}{|c|}{ Teacher-Student(s) Interaction } & \multicolumn{3}{|c|}{ Student(s)-Teacher Interaction } \\
\hline & & Number & $\begin{array}{c}\text { Percentage } \\
(\%)\end{array}$ & $\begin{array}{c}\text { Metaphorical } \\
\text { Remark }\end{array}$ & Number & $\begin{array}{c}\text { Percentage } \\
(\%)\end{array}$ & $\begin{array}{c}\text { Metaphorical } \\
\text { Remark }\end{array}$ \\
\hline 1. & Question & 134 & 32,6 & - & 1 & 0,7 & - \\
\hline 2. & Statement & 117 & 28,5 & - & 8 & 5,7 & - \\
\hline 3. & Command & 61 & 14,8 & 7 & - & - & - \\
\hline 4. & Offer & 2 & 0,5 & - & - & - & - \\
\hline \multirow[b]{2}{*}{ NO. } & \multirow{2}{*}{$\begin{array}{l}\text { Responding of } \\
\text { Speech Function }\end{array}$} & \multicolumn{3}{|c|}{ Teacher-Student(s) Interaction } & \multicolumn{3}{|c|}{ Student(s)-Teacher Interaction } \\
\hline & & Number & $\begin{array}{c}\text { Percentage } \\
(\%)\end{array}$ & $\begin{array}{l}\text { Metaphorical } \\
\text { Remark }\end{array}$ & Number & $\begin{array}{l}\text { Percentage } \\
(\%)\end{array}$ & $\begin{array}{c}\text { Metaphrical } \\
\text { Remark }\end{array}$ \\
\hline 1. & Answer & 1 & 0,2 & - & 108 & 76,6 & - \\
\hline 2. & Acknow-ledgement & 89 & 21,7 & - & 6 & 4,3 & - \\
\hline 3. & Compliance & - & - & - & 15 & 10,6 & - \\
\hline 4. & Contra-diction & 7 & 1,7 & - & - & - & - \\
\hline 5. & Disclaimer & - & - & - & 3 & 2,1 & - \\
\hline & Total Number & 411 & $100 \%$ & - & 141 & $100 \%$ & - \\
\hline \multicolumn{5}{|c|}{ Total Number of Teacher's and Students' clauses } & \multicolumn{2}{|c|}{552 Clauses } & \\
\hline
\end{tabular}


Table 4.1 above shows the number of clauses of initiating speech function produced in the interaction between teacher and students. During the learning process which was done in vocational classroom interaction, there are 552 clauses as the total number of speech function where teacher produced 411 clauses and students produced 141 clauses. Teacher produced all the four types of speech function in form of initiating (statement, offer, question, and command) and 3 types of responding of speech function (acknowledgement, contradiction, and answer). The most dominant type of speech function used by teacher among all the clauses is question with 134 clauses in teacher-to-student(s) interaction. This may mean that question was the most contributive clauses to the teaching and learning process of English in vocational classroom interaction. Unfortunately, from the three main teaching activities which are opening, the main activity, and closing, teacher did not produce any question in both opening and closing activity. So that, for all the questions had been produced by the teacher, 134 questions were only appeared in the main activities during the discussion time and discussion the reading tasks.

Meanwhile, students produced 2 types (statement and question) in form of initiating speech functions and 4 types of responding speech functions (answer, compliance, disclaimer, and acknowledgement). The most dominant type used by students among all the clauses is answer with 108 clauses in student(s)-to-teacher interaction. The number of clauses initiated by students showed that there were significant different number of clauses initiated by both teacher and the students. This proved that during the teaching and learning process, the classroom 
interaction was initiated dominantly by the teacher who always be the first to open the interaction by giving questions, commands, statements and offer.

Moreover, according to the conception of teaching proposed by Gage (2004), there are variables: (a) presage category; (b) context category; (c) process category; and (d) product which might affect to each other on the teacher's and students' performance. The data from the interview sessions showed that the underlying reasons of teacher's performance related to the existence of initiating question as the dominant speech function was affected by the teacher's belief which belongs to the presage category and context category which refers to the class in which the teaching process takes place. Meanwhile, besides the learning process was affected by the teacher's beliefs, the underlying reasons of students' performance related to the existence of answer as the dominant one was also affected by the students' perception and students' understanding which belong to the students' thought processes category and the classroom in which the learning process takes place as the variables which belong to the context category.

\section{CONCLUSIONS AND SUGGESTIONS}

\section{The Conclusions}

From the findings have been described previously, conclusions can be drawn as follows: (1) The overall teaching and learning process of reading comprehension session was oriented to the teacher-centered because the interaction was initiated dominantly by the teacher. All the four types of speech function in form of initiating (statement, offer, question, and command) and 3 
types of responding of speech function (acknowledgement, contradiction, and answer) were produced by the teacher. The most dominant type of speech function used by teacher among all the clauses is question in the interaction between teacher to student(s). Meanwhile, students produced 2 types (statement and question) in form of initiating speech functions and 4 types of responding speech functions (answer, compliance, disclaimer, and acknowledgement). The most dominant type used by students among all the clauses is answer in student(s)-to-teacher interaction. The number of clauses initiated by students showed that there were significant different number of clauses initiated by both teacher and the students. (2) The underlying reasons of teacher's performance related to the existence of initiating question as the dominant speech function was affected by the teacher's belief which belongs to the presage category and context category which refers to the class in which the teaching process takes place. Meanwhile, besides the learning process was affected by the teacher's beliefs, the reasons of students' performance related to the existence of answer as the dominant one was also affected by the students' perception and students' understanding which belong to the students' thought processes category and the classroom in which the learning process takes place as the variables which belong to the context category. 


\section{The Suggestions}

Considering the conclusions above, some suggestions are presented in this part, for teacher: (1) the teacher is expected to improve the effectiveness of teaching English related to the teacher's verbal behavior while conducting the classroom activities, and (2) teacher should pay attention on implementing the classroom activities in order to increase the students' enthusiasm. While for researchers, it is suggested to other researchers to conduct varied research in other classroom interaction sessions, for instance in reading comprehension with the other kinds of text, in writing, speaking, or listening which is considered important in improving the students' abilities and ways in learning English as well as improving the teachers' performance in the teaching process.

\section{REFERENCES}

Bogdan, R., and Biklen, S. K. (1992). Qualitative Research for Education: An Introduction to Theory and Methods. Boston: Allyn and Bacon.

Brown, H. D. 2001. Teaching by Principles: An Interactive Approach to Language Pedagogy. Second Edition. New York: Addison Wesley Longman.

Creswell, J. W. 2009. Design Qualitative, Quantitative and Mixed Methods Approaches, Third Edition. USA: Sage.

Dagarin, M. 2004. Classroom Interaction and Communication Strategies in Learning English as a Foreign. Ljubljana: ELOPE.

Eggins, S. and Slade, D. 1997. Analyzing Casual Conversation. London and Washington: Cassel.

Eggins, S. 2004. An Introduction to Systemic Functional Linguistics. 2nd Edition. New York; London: Continuum.

Fraenkel, J. R., \& Wallen, N. E. 2009. How to Design and Evaluate Research in Education. Seventh Edition. New York: McGraw-Hill Higher Education.

Gage, N. L. 2004. A Conception of Teaching. New York: Spinger. 
Halliday, M.A.K. 1994. An Introduction to Functional Grammar. 2nd Edition. London: Edward Arnold.

Halliday, M.A.K \& Matthiesen Christian M.I.M. 2004. An Introduction to Functional Grammar. 3rd Edition. London: Hodder Arnold.

Liu, M. 2014. The Social Interpretation of language and Meaning. Theory and Practice in Language Studies Vol. 4, No. 6, June 2014 pp. 1238-1242.

Saragih, A. 2014. Discourse Analysis. A Systemic Functional Approaches to the Analysis of Texts. Faculty of Languages and Arts. The State University of Medan. 